\title{
Mechanical properties of bean grains (BRSMG Majestic) coated with carnauba wax
}

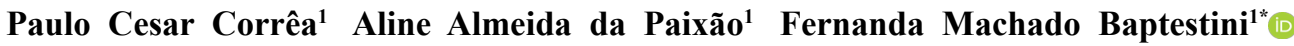 \\ Jaime Daniel Bustos Vanegas ${ }^{2}$ Juliana Soares Zeymer ${ }^{1}$
}

\begin{abstract}
${ }^{1}$ Universidade Federal de Viçosa (UFV), 36570-900, Viçosa, MG, Brasil. E-mail: fbaptestini@yahoo.com.br. "Corresponding autor.
${ }^{2}$ Universidad del Tolima, 730006299, Ibagué, Colombia.
\end{abstract}

\begin{abstract}
The objective of this research was to determine the mechanical properties of beans (BRSMG Majestuoso) coated with carnauba wax solution. Grains with 0.1481 (d.b.) moisture content was used. Treatments 0,1 and 2 were respectively defined as the control sample, application of the wax diluted 1/1 (carnauba wax solution/water) and application of carnauba wax without dilution. Uniaxial compression tests were performed in the universal test apparatus, TA HD Texture Analyzer with $500 \mathrm{~N}$ load cell. Compression tests were carried out during the storage period of in-nature grains, in those that underwent the hydration process at 40 and $50{ }^{\circ} \mathrm{C}$ of temperature and in grains during the cooking process. Only the storage time had a significant effect $(P<0.05)$ on the rupture force and the proportional deformity module. Hydration and cooking of the grains provided a reduction in the values of the studied variables.
\end{abstract}

Key words: proportional deformity modulus, cooking, rupture force.

\section{Propriedades mecânicas de grãos de feijão cultivar BRSMG Majestoso revestidos com cera de carnaúba}

\begin{abstract}
RESUMO: Objetivou-se com este trabalho determinar as propriedades mecânicas de grãos de feijão cultivar BRSMG Majestoso revestidos com cera de carnaúba. Foram utilizados grãos com teor de água de aproximadamente 0,1481 decimal b.s. (base seca), tratados com solução de cera de carnaúba. Parte destes destinou-se à amostra testemunha, uma a aplicação de cera diluída na proporção de 1/1 (solução de cera de carnaúba/água) e outra a aplicação apenas de solução de cera de carnaúba, tratamentos 0,1 e 2, respectivamente. Foram realizados ensaios de compressão uniaxiais no aparelho universal de testes, TA. HD Texture Analyser, com célula de carga de 500 N. Os testes de compressão foram realizados ao longo do periodo de armazenamento nos grãos in natura, naqueles que passaram pelo processo de hidratação nas temperaturas de 40 e $50{ }^{\circ} \mathrm{C}$ e em grãos ao longo do processo de cocção. Apenas o tempo de armazenamento teve um efeito significativo $(P<0,05)$ sobre a força de ruptura e o módulo proporcional de deformidade. A hidratação e a cocção dos grãos proporcionaram redução nos valores das variáveis estudadas.
\end{abstract}

Palavras-chave: módulo proporcional de deformidade, cocção, força de ruptura.

\section{INTRODUCTION}

The cultivar BRSMG Majestoso belongs to the commercial group of Carioca bean, presents high productivity and yield, excellent sanity, resistance to diseases and cycle of 90 days. Regarding the technological and industrial quality of the grain, it presents excellent cooking qualities, such as cooking time around 28 to 29 minutes and protein content of 23.7 to $23.9 \%$ (EPAMIG, 2016).

The beans, being marketed with moisture content around $13-14 \%$ (d.b.), need to be hydrated and processed before consumed. These can absorb water during cooking, but it is suggested to subject them to the maceration process (or hydration) before they are cooked, which consists of letting them dipped in water to rehydrate and soften, in order to facilitate cooking, improve food appearance, denature proteins, solubilize carbohydrates and gelatinize the starch (WANG et al., 2010). These changes happen due to the water absorption and continue in cooking, making the beans edible.

According to LEGRAND et al. (2007), mechanical properties are important in the measurement cooking quality and the damage magnitude throughout the processing, especially for beans, as it can be significantly altered by the time and storage conditions. Factors such as variety, location, year of production, harvest and storage, time and temperature of hydration also change the product texture. 
Influence of the heat treatment on the food texture was studied by some researchers (COELHO et al., 2009, MOURA et al., 2009, SIQUEIRA et al., 2013). For various foods, the force required to rupture decreases as the hydration temperature and cooking time increase.

Among the mechanical properties, the deformity module allows comparisons of relative strength between different materials (RESENDE et al., 2007). According to COUTO et al. (2002), in the study of the material mechanical behavior, the deformity module is considered more significant than the elasticity, since when a product is compressed, the total deformation has practical application.

Carnauba (Copernicia prunifera) is a palm tree native to the Northeastern Brazil, and can be reported across all states in that region. Leaves are palmate with a waxy coating on both surfaces (SILVA et al., 2014). The cuticular wax in plants serves as a protective agent against water loss, ultraviolet radiation, attacks by pathogens and pests (JETTER \& KUNST, 2008).

The mechanical properties of agricultural products, such as beans (ALTUNTAS \& YILDIZ, 2007; RESENDE et al., 2007), coffee (COUTO et al., 2002), wheat (FERNANDES et al., 2014), rice (RESENDE et al., 2013) and soybean (RIBEIRO et al., 2007) already been determined according to moisture content. However, during the hydration and cooking process, there are few publications in the scientific community (PARAGINSKI et al., 2014; MOURA et al., 2009). Thus, the objective of this research was to determine the mechanical properties of bean grains BRSMG Majestoso in the in-nature form, during the hydration and cooking processes. The effect of coating the bean grains with carnauba wax was also evaluated.

\section{MATERIALS AND METHODS}

Bean grains of the cultivar BRSMG Majestoso from the carioca group were harvested manually at the experimental field of the Agricultural Research Company of Minas Gerais (EPAMIG), in the city of Oratórios / MG. Afterwards, they were expurgated with fumigants, in order to avoid possible interferences of infestations occurred in the field.

Grains with 0.1481 (d.b.) of moisture content were treated with carnauba wax solution and divided into three lots of $25 \mathrm{~kg}$, of which, the treatment bean grains (TBG) factors of three levels were: control sample $(\mathrm{TBG}=0)$, application of diluted wax in $1 / 1$ ratio (carnauba / water wax solution) $(\mathrm{TBG}=$ $1)$, and carnauba wax solution $(\mathrm{TBG}=2)$.

Carnauba wax solution application was performed with a $5 \mathrm{~L}$ trombone type spray and conical jet nozzle, while the grain mass was homogenized in order to ensure the application of the solution occurred on the whole grain surface. Subsequently, the grains were scattered in suspended terrariums for drying. The moisture content of 1 and 2 treatments $(\mathrm{TBG}=$ 1 and 2) was 0.1547 and 0.1444 (d.b.), respectively.

After drying, the grains were stored in cotton bags. Every 30 days, for 8 consecutive months, $1 \mathrm{~kg}$ samples were taken for the analysis. The temperature and relative humidity of the storage environment were measured by mercury thermometer and a hair hygrometer, with daily readings at about 9 a.m.

Uniaxial compression tests were done in the Universal Testing Apparatus, TA. The HD Texture Analyzer, Stable Micro Systems, also known as texturometer, equipped with Texture Expert for Windows R software with $500 \mathrm{~N}$ load cell.

The proportional strain module was calculated using the equation below, expression of ASAE (1994), modified by COUTO et al. (2002):

$E_{p}=\frac{E}{1-\mu^{2}}=\frac{0,531 F}{D^{3 / 2}}\left[2\left(\frac{1}{r}+\frac{1}{R}\right)^{1 / 3}\right]^{2 / 3}$

where: Ep: strain proportional modulus, $\mathrm{Pa}$; $\mathrm{E}$ : deformity module, $\mathrm{Pa}$; $\mathrm{F}$ : force, $\mathrm{N} ; \mu$ : Poisson ratio, dimensionless; r: radius of curvature at the contact point, $\mathrm{m}$; R: equivalent radius of the product, $\mathrm{m}$; and $\mathrm{D}$ : Total (elastic and plastic) deformation of the body at the contact points with the upper and lower plate, $\mathrm{m}$.

The curvature radius and equivalent radius of the grains were obtained by the following equations $\quad r=\frac{a}{2} \quad$ and $R=\frac{a^{2}+\left(c^{2} / 4\right)}{2 c} \quad$ (MOHSENIN, 1986), respectively, where: a: largest grain size, m; and c: lower grain size, $\mathrm{m}$. The orthogonal axis was measured using a digital caliper with a resolution of $0.01 \mathrm{~mm}$.

Grain in-nature compression tests were carried out over the storage period, in the grains that went through the hydration process and the grains throughout the cooking process.

\section{Grains in-nature compression}

Grains were submitted to the uniaxial compression effort between two parallel plates in the resting position, at $0.001 \mathrm{~m} \mathrm{~s}^{-1}$ of force application rate. For each experimental condition, 10 bean grains were used, and the test was finalized with $0.0025 \mathrm{~m}$ of fixed deformation.

The split-plot scheme was considered. The treatments bean grains (TBG $=0,1$ and 2 ) were setting as the plots and the storage time $(0,30,60,90,120$, $150,180,210$ and 240 days) was the subplots. The design was completely randomized, with 7 replicates.

\section{Compression after grains hydration}

Grains were soaked in water for $12 \mathrm{~h}$ at 40 and $50{ }^{\circ} \mathrm{C}$ of temperature. Then, the samples 
were placed on filter paper for $2 \mathrm{~min}$ to remove water excess. Subsequently, the uniaxial compression was performed between two parallel plates with the grains in natural resting position, at $0.001 \mathrm{~m} \mathrm{~s}^{-1}$ of force application rate. The test was finalized when the $0.0025 \mathrm{~m}$ of fixed deformation was reached.

The split-plot scheme was considered. The treatments bean grains $(\mathrm{TBG}=0,1$ and 2$)$ were setting as the plots and the storage time $(0,30,60,90,120$, $150,180,210$ and 240 days) was the subplots. The design was completely randomized, with 7 replicates.

\section{Compression during the cooking process}

Beans were soaked in distilled water for 12 $\mathrm{h}$ at $20^{\circ} \mathrm{C}$ of temperature. Then, $50 \mathrm{~g}$ of samples were placed in a metal vessel held at atmospheric pressure with $500 \mathrm{~mL}$ of boiling distilled water and constant volume. At 5 min intervals, grain samples were taken for the compression tests over a period of $30 \mathrm{~min}$.

Subsequently, the uniaxial compression was performed between two parallel plates, with the grains in natural resting position, at $0.001 \mathrm{~m} \mathrm{~s}^{-1}$ of force application rate. The test was finalized when the $0.0025 \mathrm{~m}$ of fixed deformation was reached, obtaining the respective force at this point, a methodology adapted from RIBEIRO et al. (2007).

The split-plot scheme was also considered. The treatments bean grains ( $\mathrm{TGB}=0,1$ and 2) were setting as the plots, the storage time $(0,30,60,90$,
$120,150,180,210$ and 240 days) was the subplots and the times of the heat treatment $(0,5,10,15$, 20, 25 and $30 \mathrm{~min}$ ) were the subplots. A completely randomized design with 5 replications was used.

\section{RESULTS AND DISCUSSION}

There was no statistical difference between the treatments bean grains in the compression test. However, time of storage and cooking had a significant effect $(p<0.05)$ on the required force to cause a specific deformation of $0.0025 \mathrm{~m}$ in the bean grains.

Treatments with the carnauba wax solution were not efficient, in such a way, to diminish the firmness of the grains throughout the storage (Figure 1A). It was expected that the layer created by the application of the carnauba wax solution would cause a decrease in the gaseous exchanges of the grain with the environment and the enzymatic reactions, reducing the natural hardening occurring in cotyledons during storage, the call "hard-to-cook".

Figure 1A shows the increase in firmness of the grains in-nature, expressed by the maximum strength sustained by them for a given deformation, during the storage time, with a variation between 290.57 and $551.45 \mathrm{~N}$. Grains hydrated at 40 and $50^{\circ} \mathrm{C}$ (Figure 1B and $1 \mathrm{C}$ ) there was no tendency of the maximum force

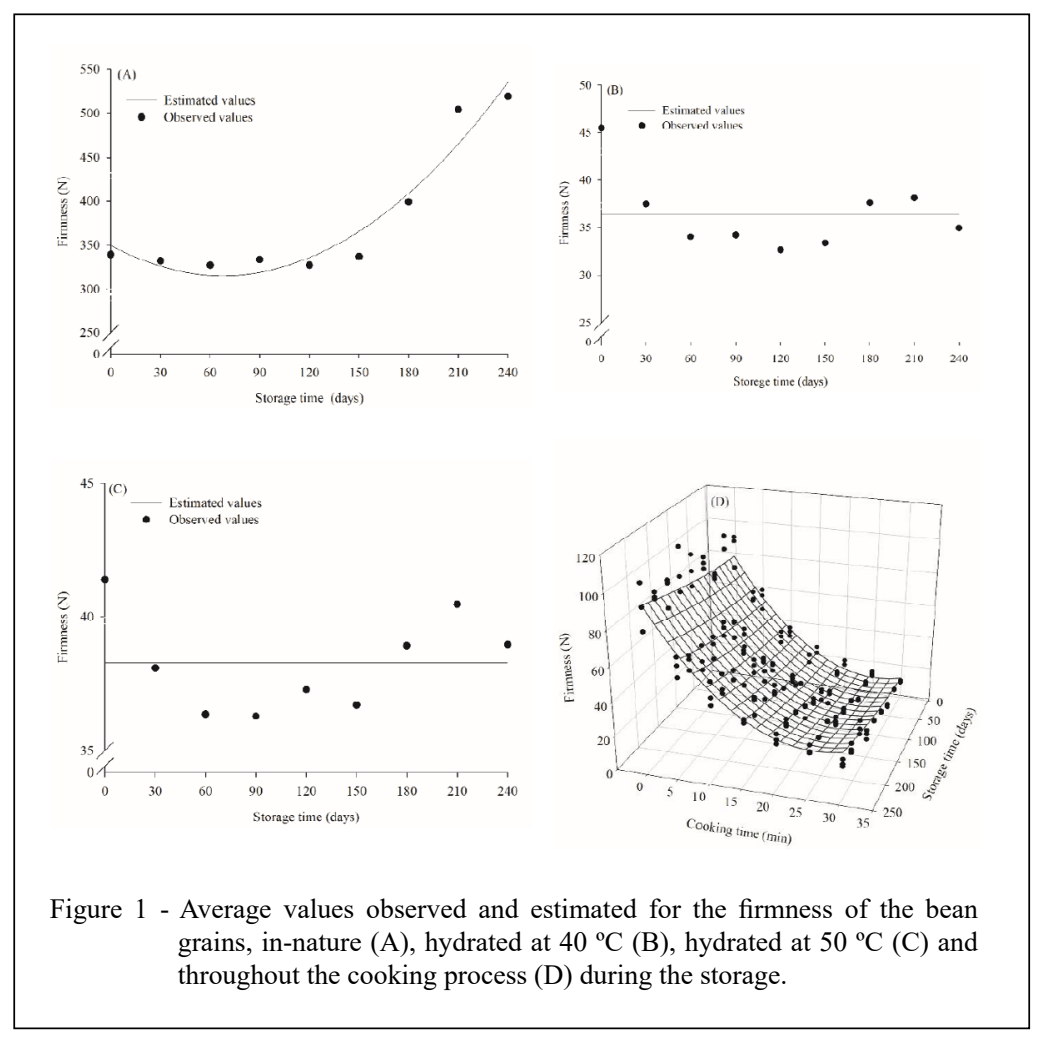

Ciência Rural, v.49, n.9, 2019. 
with storage time, being less than $60 \mathrm{~N}$. PARAGINSKI et al. (2014) reported that the maximum force for parboiled rice was 528.36 to $1990.21 \mathrm{~N}$.

Comparing the data of Figure 1A with Figures $1 \mathrm{~B}$ and $1 \mathrm{C}$, a marked reduction in the breaking strength of the grains is observed, as the hydrated grains with higher moisture content become softer, which reduces the force to break them.

Figure 1D shows a decrease in burst strength with increasing cooking time. According to OLIVEIRA et al. (2013), the development of quickbred bean cultivars meets the needs of the consumer market, which has reduced time to prepare meals and reduces energy costs. Bean cultivars with cooking time of less than $30 \mathrm{~min}$ are desirable because it means energy and capital savings.

SIQUEIRA et al. (2013), evaluated different methods of cooking carioca beans, cultivar Pérola, freshly harvested and stored at room temperature for seven months. Through the analysis of resistance to the compressive force, was verified that, as the cooking time of the beans increased, the resistance to the compressive force reduced for both the freshly harvested and the stored grains.

COELHO et al. (2009) compared the changes in cooking time and strength to compressive strength of common bean grains Iapar 81 and Iapar 44 during storage. The authors reported that the compressive force of two varieties increased with increasing storage time, in cooked and cooled beans up to ambient temperature and up to $60{ }^{\circ} \mathrm{C}$.

Table 1 shows the statistical models that best fit the firmness data of the bean grains in-nature (A), hydrated at $40{ }^{\circ} \mathrm{C}(\mathrm{B})$, hydrated at $50{ }^{\circ} \mathrm{C}(\mathrm{C})$ and throughout the cooking process (D). Due to the large variability of the data and the absence of statistical significance between them, the maximum force was represented only by the average data observed for the hydrated grains at 40 and $50{ }^{\circ} \mathrm{C}$. For in-nature grains and throughout the cooking process, the model explains 77.97 and $92.60 \%$ of the observed data variation (Table 1).

The model that adjusted to the maximum force data during the cooking process presented a quadratic relationship with the storage time and the cooking time, which indicates that the force needed to cause a specific deformation is directly influenced by the storage and cooking time (Table 1). The increase in cooking time causes significant reduction in strength. In the storage and cooking time 0 , the minimum strength observed was $71.85 \mathrm{~N}$. At 60 days of storage and cooking time of $30 \mathrm{~min}$ the minimum strength was $8.58 \mathrm{~N}$. The maximum strength observed in 60 days of storage and $0 \mathrm{~min}$ of cooking was $109.32 \mathrm{~N}$ and for 180 days of storage and 30 min of cooking was $30.14 \mathrm{~N}$.

According to COUTO et al. (2002), in the study of the material mechanical behavior, the proportional deformity module is considered more significant than the elasticity, since, when a product is compressed, the total deformation has practical application. The proportional deformity module did not show significant differences between the treatments bean grains (TBG) (Figure 2).

Figure 2 show that the proportional deformity module presents a similar tendency to the compression force. This result is in agreement with conclusions obtained by COUTO et al. (2002), who studied coffee beans and argued that the larger the proportional deformity module, the greater the force required to accelerate the product deformation.

Table 1 - Models adjusted for the firmness of the bean grains in-nature (A), hydrated at $40{ }^{\circ} \mathrm{C}(\mathrm{B})$, hydrated at $50{ }^{\circ} \mathrm{C}(\mathrm{C})$ and throughout the cooking process (D) as a function of storage time $(t)$ in days and the cooking time $\left(t_{c o c}\right)$ in min, with their respective coefficients of determination.

\begin{tabular}{lcc}
\hline & $\hat{F}=349.425^{* *}-1.002^{*} t+0.007^{* *} t^{2}$ & $\mathrm{R}^{2}(\%)$ \\
\hline (A) & $\hat{F}=36.422$ & 77.97 \\
(B) & $\hat{F}=38.271$ & \\
(C) & $\hat{F}=78.701^{* *}+0.026 t-5.281^{* *} t_{c o c}+0.0002 t^{2}+0.102^{* *} t_{c o c}^{2}$ & 92.60 \\
(D) &
\end{tabular}

\footnotetext{
${ }^{* *}$ Significant at $1 \%$ probability by t-test; ${ }^{*}$ Significant at $5 \%$ probability by t-test.
} 
The proportional deformity module values decreased abruptly when the bean grains were submitted to the hydration process, showing the effect of the water gain on the grain softness. According to LEGRAND et al. (2007), the proportional deformity module quantifies the textural changes of particles during the heat treatment. It is also observed lower values for the grains that only went through the hydration process at 40 and $50{ }^{\circ} \mathrm{C}$ (Figure $2 \mathrm{~B}$ and $2 \mathrm{C}$ ), when compared to those submitted to the compression test after the cooking process at zero time (Figure 2D) .

RESENDE et al. (2007) evaluated the mechanical behavior of red bean grains as a function of moisture content. Based on the estimated equation, was reported values of $1,383.3 \mathrm{MPa}$ for $0.002 \mathrm{~m}$ deformation and 0.1 (d.b.) moisture content, while for the same deformation and 0.2 (d.b.) moisture content they reported values of $1310.0 \mathrm{MPa}$.
In the compression test after beans cooking, were observed minimum values of 817.60 $\mathrm{MPa}$ at storage and cooking time 0 and $9.65 \mathrm{MPa}$ at 60 days storage and cooking time of $30 \mathrm{~min}$. The maximum values observed were $1212.03 \mathrm{MPa}$ observed in 60 days storage and 0 min of cooking, and of $344.43 \mathrm{MPa}$ in 180 days storage and $30 \mathrm{~min}$ of cooking (Figure 2D).

Similar to the force, a characteristic behavior of the grains submitted to hydration at 40 and $50{ }^{\circ} \mathrm{C}$ was not verified in the data of the proportional deformity module. Due to the lack of adjustment of a model to the observed data, the module was represented by the observed values mean. The other models, which represent the proportional deformity module of grain in-nature and throughout the cooking process, presented good determination coefficients and significance of the regression coefficients (Table 2).

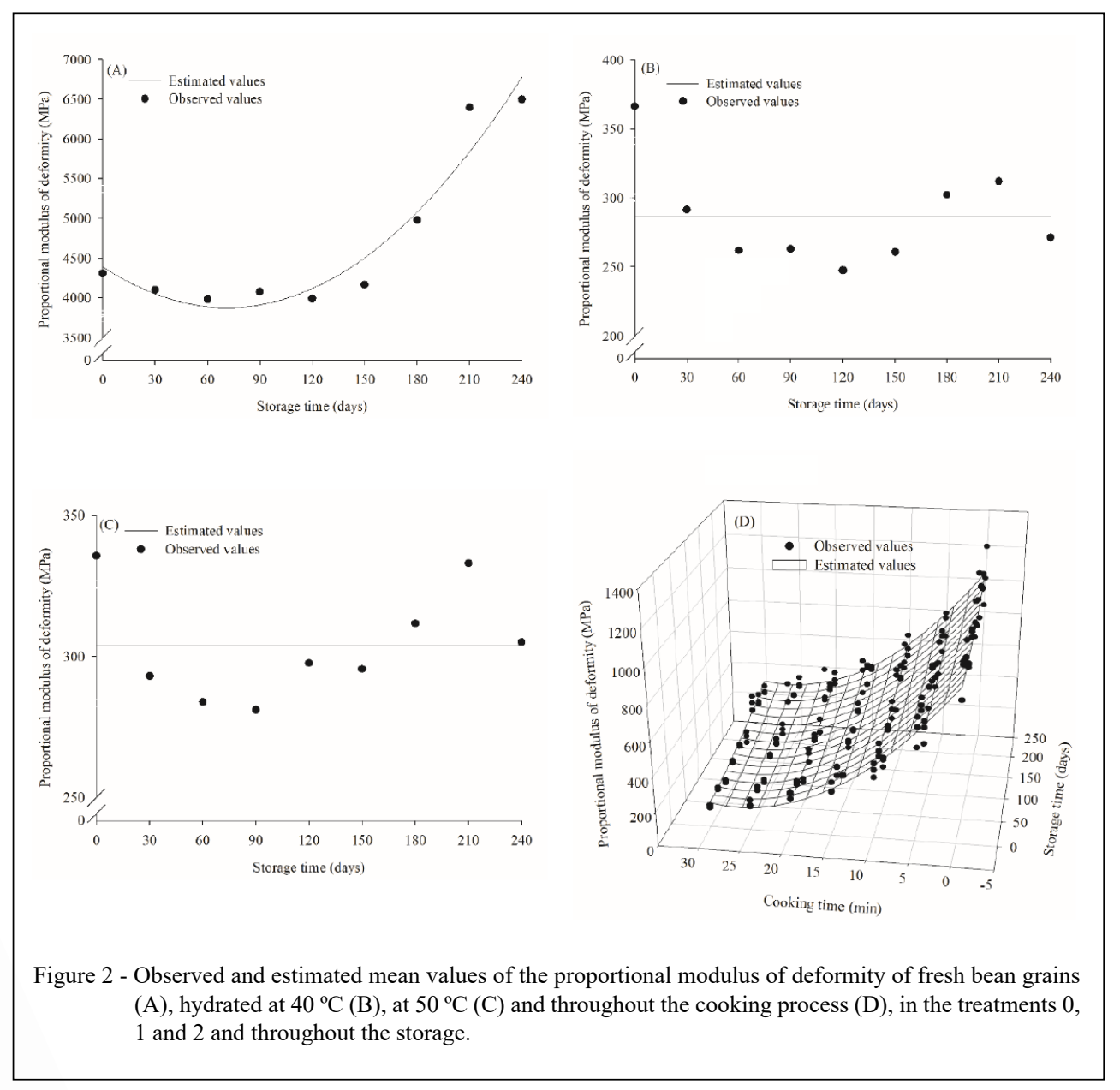

Ciência Rural, v.49, n.9, 2019. 
Table 2 - Adjusted models for the proportional deformity module of bean grains in-nature (A), hydrated at $40{ }^{\circ} \mathrm{C}(\mathrm{B})$, at $50{ }^{\circ} \mathrm{C}(\mathrm{C})$ and throughout the cooking process (D) as a function of storage time $(\mathrm{t})$ in days and cooking time $\left(\mathrm{t}_{\mathrm{coc}}\right)$ in min, with their respective coefficients of determination.

\begin{tabular}{lcc}
\hline & & \\
\hline (A) & $\hat{E}_{P}=4395.194^{* *}-14.556^{* *} t+0.102^{* *} t^{2}$ & 76.97 \\
(B) & $\hat{E}_{P}=286.328$ & \\
(C) & $\hat{E}_{P}=304.167$ & 92.58 \\
(D) & $\hat{E}_{P}=889.421^{* *}+0.212 t-57.27^{* *} t_{c o c}+0.002^{*} t^{2}+1.079^{* *} t_{c o c}^{2}$ & \\
\hline
\end{tabular}

${ }^{* *}$ Significant at $1 \%$ probability by t-test; ${ }^{*}$ Significant at $5 \%$ probability by t-test.

\section{CONCLUSION}

Only the storage time had a significant effect $(p<0.05)$ on the force of rupture and the proportional deformity module. Grains hydration and cooking provided a reduction in the variables studied values.

\section{ACKNOWLEDGEMENTS}

The authors thank Coordenação de Aperfeiçoamento de Pessoal de Nível Superior (CAPES) and the Department of Agricultural Engineering of Universidade Federal de Viçosa for providing research funding and scholarship.

\section{DECLARATION OF CONFLICT OF INTERESTS}

The authors declare no conflict of interest. The founding sponsors had no role in the design of the study; in the collection, analyses, or interpretation of data; in the writing of the manuscript, and in the decision to publish the results.

\section{AUTHORS' CONTRIBUTIONS}

All authors contributed equally for the conception and writing of the manuscript. All authors critically revised the manuscript and approved of the final version.

\section{REFERENCES}

ALTUNTAS, E.; YILDIZ, M. Effect of moisture content on some physical and mechanical properties of faba bean (Vicia faba L.) grains. Journal of Food Engineering, v.78, p.174183, 2007. Available from: <http://dx.doi.org/10.1016/j. jfoodeng.2005.09.013>. Accessed: Oct. 09, 2018. doi: 10.1016/j. jfoodeng.2005.09.013.

COELHO, S.R.M. et al. Alterações no tempo de cozimento e textura dos grãos de feijão comum durante o armazenamento. Ciência e Agrotecnologia, v.33, p.539-544, 2009. Available from: <http://
dx.doi.org/10.1590/S1413-70542009000200028>. Accessed: Oct. 09, 2018. doi: 10.1590/S1413-70542009000200028.

COUTO, S.M. et al. Comportamento mecânico de frutos de café: módulo de deformidade. Revista Brasileira de Engenharia Agrícola e Ambiental, v.6, p.285-294, 2002. Available from: <http://dx.doi.org/10.1590/S1415-43662002000200018>. Accessed: Oct. 09,2018. doi: 10.1590/S1415-43662002000200018.

EPAMIG. Empresa de Pesquisa Agropecuária de Minas Gerais. Cultivares de feijão recomendadas para o estado de Minas Gerais. Belo Horizonte, 2016. Available from: <file:///C:/Users/USUARIO/ Downloads/cultivares_de_feijao_recomendadas_para_o_estado_de_ minas_gerais\%20(1).pdf.>. Accessed: Oct. 09, 2018.

FERNANDES, L.S. et al. Influência do teor de água nas propriedades mecânicas dos grãos de trigo submetidos à compressão. Bioscience Journal, v.30, p.219-223, 2014. Available from: $<$ http://www.seer.ufu.br/index.php/biosciencejournal/article/ viewFile/18008/14570>. Accessed: Oct. 09, 2018.

JETTER, R; KUNST, L. Plant surface lipid biosynthetic pathways and their utility for metabolic engineering of waxes and hydrocarbon biofuels. The Plant Journal, v.54, p.670-683, 2008. Available from: <https://doi.org/10.1111/ j.1365-313X.2008.03467.x> Accessed: Oct. 09, 2018. doi: 10.1111/j.1365-313X.2008.03467.x.

LEGRAND, A. et al. Physical, mechanical, thermal and electrical properties of cooked red bean (Phaseolus vulgaris L.) for continuous ohmic heating process. Journal of Food Engineering, v.81, p.447-458, 2007. Available from: <http://dx.doi.org/10.1016/j. jfoodeng.2006.11.024>. Accessed: Oct. 09, 2018. doi: 10.1016/j. jfoodeng.2006.11.024

MOHSENIN, N.N. Physical properties of plant and animal materials. New York: Gordon and Breach, 1986. 841p.

MOURA, N.C. et al. Características físicas de quatro cultivares de soja crua e submetidas a diferentes tratamentos térmicos. Alimentos e Nutrição Araraquara, v.20, p.383-388, 2009. Available from: <http://serv-bib.fcfar.unesp.br/seer/index.php/ alimentos/article/viewFile/1131/834>. Accessed: Oct. 09, 2018

Ciência Rural, v.49, n.9, 2019. 
OLIVEIRA, V.R. et al. Perfil sensorial de cultivares de feijão sob diferentes tempos de cozimento. Alimentos e Nutrição Araraquara, v.24, p.145-152, 2013. Available from: <http:// serv-bib.fcfar.unesp.br/seer/index.php/alimentos/article/ viewFile/145/2188> Accessed: Oct. 09, 2018.

PARAGINSKI, R.T. et al. Propriedades tecnológicas e de cocção em grãos de arroz condicionados em diferentes temperaturas antes da parboilização. Brazilian Journal of Food Technology, v.17, p.146-153, 2014. Available from: <http://dx.doi.org/10.1590/ bjft.2014.021>. Accessed: Oct. 09, 2018. doi: 10.1590/bjft.2014.021.

RESENDE, O. et al. Comportamento mecânico dos grãos de feijão submetidos a compressão. Revista Brasileira de Engenharia Agrícola e Ambiental, v.11, p.404-409, 2007. Available from: $<$ http://dx.doi.org/10.1590/S1415-43662007000400010>. Accessed: Oct. 09, 2018. doi: 10.1590/S1415-43662007000400010.

RESENDE, O. et al. Mechanical properties of rough and dehulled rice during drying. International Journal of Food Studies, v.2, p.158-166, 2013. Available from: <http://dx.doi.org/10.7455/ ijfs/2.2.2013.a3>. Accessed: Oct. 09, 2018. doi: 10.7455/ ijfs/2.2.2013.a3.
RIBEIRO, D.M. et al. Propriedades mecânicas dos grãos de soja em função do teor de água. Engenharia Agrícola, v.27, p.493500, 2007. Available from: <http://dx.doi.org/10.1590/S010069162007000300019>. Accessed: Oct. 09, 2018. doi: 10.1590/ S0100-69162007000300019.

SILVA, P.S.L. et al. Doses of carnauba leaf residues and corn yield. Horticultura Brasileira, v.32, p.74-79, 2014. Available from: <http://dx.doi.org/10.1590/S010205362014000100012>. Accessed: Oct. 09, 2018. doi: 10.1590/ S0102-05362014000100012.

SIQUEIRA, B.S. et al. Hardness of carioca beans (Phaseolus vulgaris L.) as affected by cooking methods. Food Science and Technology, v.54, p.13-17, 2013. Available from: <http://dx.doi. org/10.1016/j.lwt.2013.05.019>. Accessed: Oct. 09, 2018. doi: 10.1016/j.lwt.2013.05.019.

WANG, N. et al. Effect of cooking on the composition of beans (Phaseolus vulgaris L.) and chickpeas (Cicer arietinum L.). Food Research International, v.43, p.589-594, 2010. Available from: $<$ http://dx.doi.org/10.1016/j.foodres.2009.07.012>. Accessed: Oct. 09, 2018. doi:10.1016/j.foodres.2009.07.012. 